\section{The Sino-Japanese energy dispute in the East China Sea: strategic policy, economic opportunities, and cooperation}

\section{James Manicom}

$\mathrm{T}$

here is a consensus in the literature that Chinese and Japanese energy security policies are competitive and that this necessarily precludes long-term energy cooperation in the East China Sea. According to Liao Xuanli, this competition has emerged due to political mistrust and the worsening of the strategic relationship since the end of the cold war. Furthermore, these factors outweigh similar Sino-Japanese energy security vulnerabilities, such as a reliance on imported oil, mostly from the Middle East. ${ }^{1}$ There are also striking similarities in the countries' energy security policies: both seek to "go out" and gain direct access to upstream oil sectors. However, the nature of these policies reinforces zero-sum thinking because these upstream opportunities are finite in number. Zero-sum thinking is further reinforced by the geopolitical considerations that are driving regional energy security policies across the Asia-Pacific region. ${ }^{2}$

An extension of this argument is that the competitive nature of regional energy security policy precludes cooperation in a territorial dispute in which hydrocarbon resources are at stake. In this view, Chinese and Japanese energy insecurity underwrites resolve on both sides to pursue disputed resources at any cost and eschew cooperation. ${ }^{3}$ Both parties have sought to ensure that resource exploration occurs in areas that are least damaging to their jurisdictional claims. Japan has always opposed joint development in the area surrounding the disputed Senkaku/Diaoyu islands, while China has been reluctant to consider projects elsewhere in the East China Sea. Consistent with each party's delimitation preferences, China has attempted to push its claims as far east, and Japan as far west, as possible. Even those who are optimistic about broad Sino-Japanese energy cooperation due to synergies in energy efficiency technologies and environmental management are pessimistic about sustained cooperation in the East China Sea dispute. ${ }^{4}$

Nevertheless, an agreement announced on 18 June 2008 between China and Japan indicates a degree of political will to cooperate on territorial and energy issues. The aim of this article is to ascertain, based on past trends in energy cooperation, whether the June agreement can be made sustainable. The article proceeds in three sections. The first outlines the East China Sea territorial dispute, the energy stakes, and the terms of the June agreement. The second surveys past instances of Sino-Japanese energy cooperation with specific reference to the maritime realm. The final section analyzes the strategic and economic trends of this background and explores implications for the future of the June agreement.

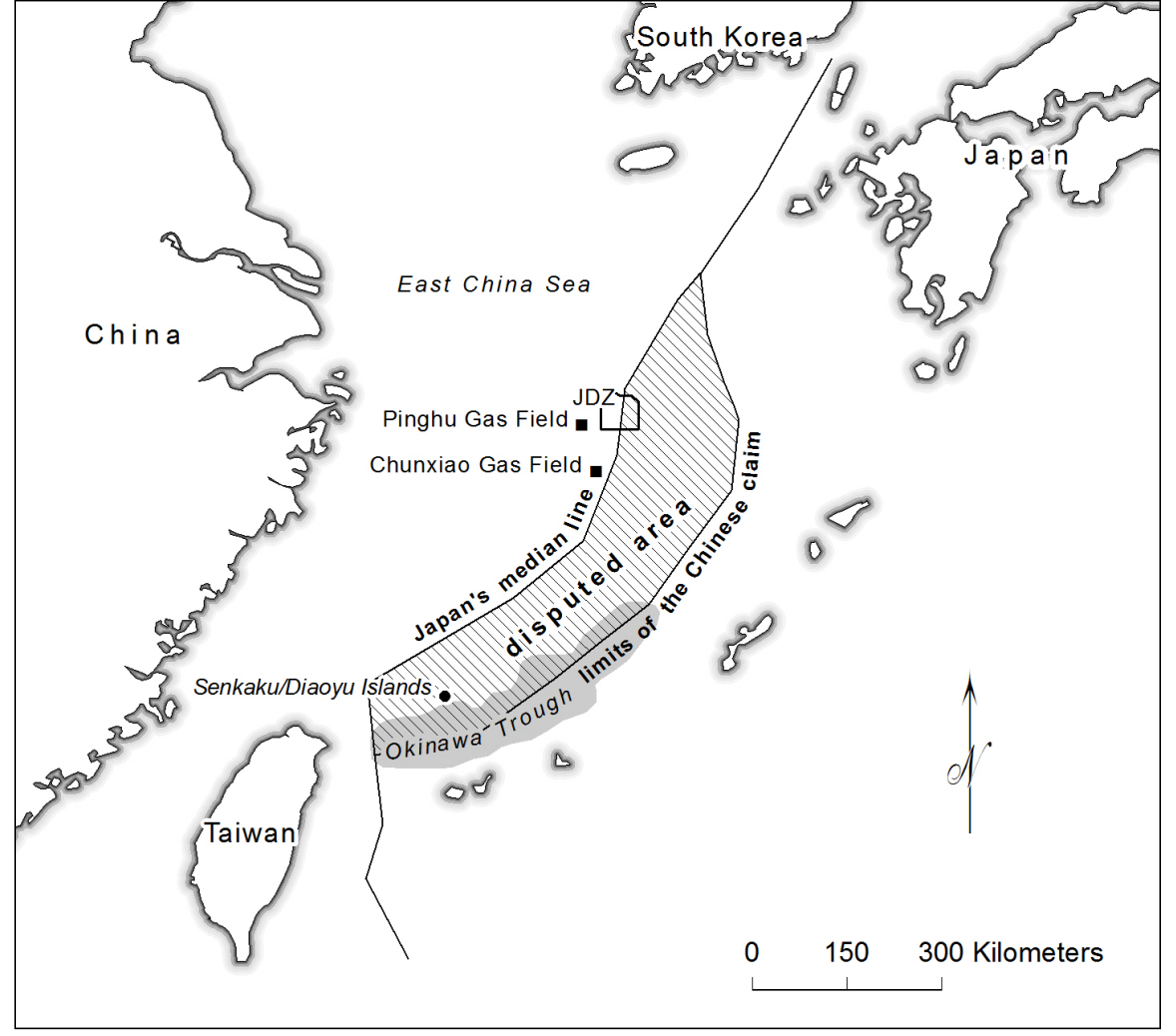

Figure 1: The East China Sea

The East China Sea dispute: resource stakes and the June agreement

As indicated in Figure 1, the dispute over resource development in the East China Sea is centered on the Chinese development of the Chunxiao gas field located $5 \mathrm{~km}$ from Japan's claimed median line. The Chunxiao dispute is connected with the Senkaku/Diaoyu islands dispute and the wider question of maritime delimitation in the East China Sea. China contests Japanese sovereignty over the islands, and both states included them in their respective Exclusive Economic Zone (EEZ) and continental shelf declarations in 1996. China claims a continental shelf as far as the Okinawa trough based on the natural prolongation of its land territory. Japan claims an EEZ to a median line that bisects the East China Sea. Chinese leaders do not officially recognize the Japanese median line. Both delimitation methods are recognized under the U.N. Convention on the Law of the Sea (UNCLOS). The 
delimitation dispute goes directly to the heart of the Chunxiao dispute. ${ }^{5}$

\section{The Chunxiao dispute: background and stakes}

The dispute over Chunxiao stems from a disagreement over the location of the disputed area in the East China Sea, and by extension the area subject to joint development. China argues that Chunxiao lies in Chinese waters on the west side of the median line and that therefore, even according to the Japanese interpretation of international law, there is nothing wrong with the Chunxiao project. The Chinese argue that the disputed area in the East China Sea is between the Japanese-claimed median line and the Okinawa trough, which marks the limit of the Chinese continental shelf claim. As indicated by Figure 1, this is the area of overlap between the two maritime claims. Japan protested the Chinese activities at Chunxiao in August 2003 and claims that the Chunxiao field, as well as the neighboring Tianwaitian, Duanqiao, and Longjing fields extend on to the east side of the median line into its EEZ and that, consequently, it is entitled to a share of the resources produced. Japan has commissioned surveys of the median area that confirmed its suspicions and in July 2005 granted Teikoku Oil the right to conducted exploratory drilling on the east side of the median line. China protested that these were attempts to alter the status quo. As of April 2009, drilling had not commenced.

The total resource value of the Xihu trough, the geological formation on which the gas fields are formed, is unknown. Estimates of potential reserves in the East China Sea vary but the operator of the Chunxiao field, the Chinese National Offshore Oil Company (CNOOC), estimates total gas reserves to be between 175 and 250 trillion cubic feet (cf) and total oil reserves to be between 70 and 160 billion barrels. $^{6}$ Currently, the highest expectations of the Xihu trough are for natural gas, up to 17.5 trillion $\mathrm{cf}$ in the entire basin and 363.9 billion cf at Chunxiao. None of the contested Xihu trough fields is producing oil at a commercial rate. While these estimates may be inflated, due to this uncertainty both China and Japan are reluctant to make concessions on maritime boundary delimitation that may undermine their claim to the entire sea.

\section{The East China Sea in Chinese and Japanese energy security}

The exploitation of East China Sea resources is consistent with two Chinese energy security strategies: diversification of primary energy sources and diversification of import sources. To diversify energy sources, China has prioritized a greater reliance on natural gas in eastern China. Natural gas consumption is projected to be raised from 2 percent currently to between 8 and 10 percent by $2020{ }^{7}$

In light of these plans to increase supply in coastal areas, offshore natural gas resources could play an important role, particularly when considered in the context of existing problems with China's domestic gas reserves. Domestic reserves are far from their intended markets, while imported liquefied natural gas (LNG) is only economical close to coastal terminals. Alternatively, offshore natural gas fields in the East and South China Seas are "welcome exceptions to this rule." Early expectations were that CNOOC's gas projects in the East China Sea could fuel the economies of Shanghai, Zhejiang province, and Hong Kong and perhaps be more economical than gas piped from Xinjiang province through the West-East pipeline.

In addition to diversifying the energy mix, this market proximity provides a degree of supply security. Although self-sufficiency has historically been a top priority for Chinese leaders, China's oil import dilemma has forced its leaders to look overseas. Consequently, Chinese entities pursue projects in a wide variety of locations in order to minimize the potential for supply disruption from foreign powers or price volatility. While these "equity oil" stakes give assurance of supply, they are not necessarily the most cost effective option because price volatility can cause a host country to renegotiate the terms of an agreement. In light of these concerns, the East China Sea could provide China with a source of oil and gas close to intended markets and less vulnerable to sea lane disruption.

As for Japan, according to its Agency for Natural Resources and Energy (ANRE) energy security threats include: political conditions in the Middle East, incidental threats such as terrorism or natural disasters, reduction of investments or market manipulation by supply nations, demand trends in importing nations such as China and India, and mismanagement of the domestic energy industry. ${ }^{9}$ The exploitation of East China Sea resources addresses these energy security threats in three ways. First, it is consistent with Japan's aim to diversify energy sources away from the Middle East. Second, due its geographic proximity, East China Sea resource production avoids the sea lane choke points that oil and LNG bound for Japan pass through. Third, the exploitation of natural gas supports Japan's energy diversification plans, thereby partly reducing its vulnerability to oil price shocks. Natural gas is to be increased from 15 to 18 percent of the primary energy mix by 2020 . Therefore, the long-term prospects of East China Sea resources have the potential to alleviate some of the threats to Japanese energy security.

The June 2008 agreement in the East China Sea dispute

The three-part agreement was achieved following four years of negotiations. The first part outlines a $2,700 \mathrm{~km}^{2}$ joint development zone (JDZ) south of the Longjing field that, roughly, bisects the median line (see Figure 1). According to the declaration, joint exploration of the zone will be conducted and developed "under the principle of mutual benefit." 10 The second part of the agreement permits Japanese entities to invest in the Chunxiao field in a manner consistent with Chinese law. The third part calls for a treaty to be signed to implement the agreement. The agreement is not an agreement on resource exploitation, nor does it delimit boundaries in the East China Sea. At best, it is an agreement on the most basic positions of China and Japan. The first part of the 
agreement indicates a Chinese willingness to be flexible because the proposed joint development area straddles the median line. The second part, a specific reference to the development of the Chunxiao field, is likely a result of the Japanese argument that because the geological features of the field extend across the median line, it is entitled to a share of resources produced. Under these provisions Japanese companies would play an identical role to that of Shell and UNOCAL prior to their exit from the Chunxiao project in September 2004. ${ }^{11}$

Since June 2008 there has been no progress toward either the conclusion of the treaty or Japanese participation at Chunxiao. Japanese media have speculated that this may be due to internal criticisms of the Chinese leadership because of the concessions it made during the negotiations. ${ }^{12}$ A more likely reason may be the collapse of the nominal global oil price from US\$127 per barrel just after the agreement was concluded. This is not an oil market that is conducive to costly offshore exploration. However, as argued in the next section, oil prices alone have rarely dictated the tone and pace of Sino-Japanese energy cooperation; strategic prerogatives have been equally important.

\section{Sino-Japanese energy cooperation: origins and depth}

To assess the sustainability of the June 2008 agreement, this section explores the Sino-Japanese track record on energy cooperation. Historically, Sino-Japanese cooperation in the field of energy and offshore resource development has been driven by the nexus between strategic prerogatives and economic opportunities. The former includes the management of the bilateral relationship in the context of exogenous factors like the Soviet threat and was driven by policy elites. The latter was driven by business and government actors in the context of compatibilities between Chinese and Japanese economic interests. For instance, the East China Sea dispute first erupted in 1970 following reports of immense resource wealth near the Senkaku/Diaoyu islands. Japanese efforts to develop the area with Taiwan and South Korea were stymied by strong Chinese rhetoric. Bilateral tensions did not last long. The first oil crisis and China's strategic realignment against the Soviet Union created the opportunity for diplomatic rapprochement underwritten by energy cooperation.

Following the first oil crisis, Japan began to import Chinese heavy crude as part of its diversification strategy to alleviate its import dependence on the Middle East which at the time provided 85 percent of Japan's oil imports. This was consistent with both Japanese energy security imperatives as well as the strategic imperative of improving relations with China as it tilted toward the West. Following diplomatic recognition in 1972, Japanese policymakers were confident that Chinese oil exports could be depended upon as long as bilateral relations remained positive. Japanese oil imports from China peaked in 1975 after which time they decreased due to incompatibilities with Japanese refineries, compounded by a reduction in Japanese oil demand. In addition to the strategic imperative of balancing against the Soviet Union,
China also had economic incentives for energy cooperation with Japan during this period. The need for U.S. dollars underwrote the development of the onshore Chinese petroleum industry as well as China's national development. (The global oil market is conducted in U.S. dollars.) Such was this need that Chinese heavy industry tolerated energy shortages so that China could export its oil to earn foreign exchange. Chinese leaders also kept domestic oil consumption low by stressing the use of coal to free up oil for export as part of a strategy to raise U.S. dollars. ${ }^{13}$

The Senkaku/Diaoyu islands dispute flared up again during normalization negotiations in 1978. Following an attempt by pro-Taiwan Japanese Diet members to undermine talks by calling for the addition of the Senkaku/Diaoyu islands to the agenda, Deng Xiaoping issued his famous dictum that the sovereignty question be shelved for future generations and that the parties focus on joint development. The normalization agreement facilitated cooperation in the development of China's petroleum industry, not least because the Chinese and Japanese energy sectors were highly compatible. China required capital and technical advice, while Japan sought preferential access to China's vast onshore hydrocarbon resources. This relationship also rekindled discussion on the joint development of the East China Sea.

As Japanese oil imports decreased through the 1970s, China sought to reinforce political rapprochement by bringing Japanese oil companies into partnerships in the Bohai gulf, China's first offshore oil exploration zone. Japan regarded the proximity of the highly prospective gulf as an enormous gain for energy security, and Japanese oil companies were the first foreign entities to enter the area in the early 1980s Simultaneously, delegations of Chinese geologists and petroleum engineers visited Japan to learn about offshore drilling, to visit refineries, and to hold technical discussions with their Japanese counterparts. During these talks both parties expressed a willingness to consider the joint development of the area surrounding the disputed Senkaku/Diaoyu islands. However, two-day working level discussions between Law of the Sea experts in Beijing in November 1980 revealed the degree of the impasse between the two. ${ }^{14}$

The talks stumbled on the delimitation dispute. Although Japan's median line policy was not declared with regard to the EEZ until 1996, Japanese negotiators used the median principle in these early discussions. ${ }^{15}$ Although both sides had shelved the sovereignty dispute over the islands, there was still no consensus on the location of the disputed area in the East China Sea. Its joint development remained hostage to the delimitation dispute throughout the 1980s and 1990s. Nevertheless, Japan remained committed to assisting China's national development in order to ensure the emergence of a responsible Chinese power. While the strategic rationale for close energy links may have evaporated following the cold war, there remained strong commercial and energy security incentives for Japanese entities to invest in the Chinese energy sector. The renaissance of Chinese exploration activity, driven by its shift to oil importer status in 1993, provided an opportunity for further cooperation.

In 1991, the government-funded Japan National Oil Corporation (JNOC) became 
the first foreign company to invest in exploration projects in the Tarim basin. Some argue that, indicative of Japan's unique place in the Chinese energy sector, JNOC was given advance notice of the bidding round in order to improve China's chances of securing Japanese involvement. This speaks to the need for Japanese technical expertise in China's onshore oil industry at the time. Offshore, Japanese involvement in the South China Sea permitted significant advances in Chinese drilling technology. In the East China Sea, a Japanese consortium secured two blocks on the west side of the median line. However, some view the absence of other bids by Japanese companies as evidence that the disputed islands had adversely affected the interest of Japanese oil companies in the East China Sea. Nevertheless, Japanese companies remained heavily involved in the development of South China Sea and Bohai gulf resources. ${ }^{16}$

This reluctance is certainly a possibility when considered against the efforts of some Japanese companies to pursue cooperative resource development in the disputed area of the East China Sea. In light of continued Chinese need for Japanese capital and expertise, informal discussions on joint development took place at the bureaucratic and private sector levels throughout the 1980s. ${ }^{17}$ Beginning in 1985, JAPEX held talks with Chinese government officials on joint development, while Teikoku Oil separately proposed joint seismic exploration with CNOOC. Despite these efforts, talks remained preoccupied with the location of a joint development scheme. CNOOC proposed a joint development area surrounding the Senkaku/Diaoyu islands to Uruma Resources Exploration Company in mid-1987. Simultaneously, a Japanese mission proposed a $100,000 \mathrm{~km}^{2} \mathrm{JDZ}$ that straddled the median line. Because CNOOC requested that Uruma fund the joint operations, as is consistent with Chinese law, it can be inferred that Chinese negotiators were adopting a relatively inflexible position by applying domestic Chinese laws to a bilateral joint development scheme.

In addition to Chinese intransigence, the efforts of Japanese oil companies were undermined by the Japanese government, which chose to simply ignore the issue of resource development on the east side of the median line. In the absence of a common Soviet threat, Japanese leaders calculated that relations with China could be maintained through a blend of economic assistance and a diplomatic posture that glossed over differences. Although it considered a protest in 1996 to Sinopec's development of the Pinghu field, Japan was generally ambivalent about Chinese resource development in the East China Sea. For instance, it issued only diplomatic protests in response to repeated intrusions of Chinese resource exploration vessels across Japan's claimed median line. ${ }^{18}$ Furthermore, despite concerns from some Diet members, there is evidence that Japanese government entities were complicit in Chinese resource development in disputed areas of the East China Sea. In 1996, the Asian Development Bank granted a loan to fund the construction of a pipeline from the Pinghu field to the Chinese mainland. This was embarrassingly revealed at the height of the Chunxiao gas dispute in 2005. While the Pinghu field is located west of the median line, some in Japan argue that because it is within 200 nautical miles of
Japan's coast, the government should have opposed its construction rather than facilitated it. ${ }^{19}$

Japan's posture toward China's resource development in the East China Sea was defensible to a domestic audience for much of the 1990s because Chinese efforts to develop the west side of the median line were generally unsuccessful. Indeed, the Chunxiao field's discovery in 2001 was hailed as the mark of resurgent prospects in the East China Sea. Actual production in the East China Sea fell behind expectations through the 1990s, which in turn reduced the interest of international partners in East China Sea production. By the end of the millennium, low global oil prices and poor showing from test drilling made Chinese contract terms unpalatable to most multinational oil companies.

CNOOC's discovery of the Chunxiao field in 2001, combined with the state of the Sino-Japanese relationship at the time undermined Japan's posture. Japanese conservatives and media had become more critical of China following Chinese nuclear tests in 1995 and its military posture toward Taiwan in 1996. By the turn of the century, Japanese policymakers became more assertive toward China and less preoccupied with maintaining political relations, particularly since economic relations appeared to develop independently of the bilateral climate. In China, following the adoption of market socialism, the Chinese Communist Party increasingly relied on assertive anti-Japanese nationalism to legitimize its rule. As a result, Chinese leaders severed all high-level contacts with their Japanese counterparts due to Prime Minister Junichiro Koizumi's annual visits to the Yasukuni shrine between 2001 and 2005.

This bilateral climate contributed to the emergence of the zero-sum dynamics outlined earlier. Rising oil import dependence and an increasingly hostile bilateral relationship underwrote a perception on both sides that energy security had become a zero-sum game. This perception was reinforced by China's development projects at Chunxiao. In the Japanese mind-set this was tantamount to the theft of Japanese resources. Furthermore, CNOOC's emergence as a globally competitive oil company eroded commercial incentives for cooperation. CNOOC no longer required Japanese capital or technological assistance to conduct offshore exploration as indicated by the scale of its offshore projects. The Chunxiao field is entirely operated by CNOOC and Sinopec, despite the withdrawal of UNOCAL and Shell.

Following the Japanese discovery of a drilling installation at the Chunxiao field in 2003, tension over the East China Sea once again escalated. As noted, neither party was interested in compromise for fear of surrendering their claim to the entire disputed area. Japanese leaders altered their posture in October 2005 and tabled a joint development proposal. Subsequent joint development negotiations took place between March 2006 and December 2007 and yielded tangible progress in step with the improvement in bilateral relations. ${ }^{20}$ The June 2008 agreement is a product of these talks and is indicative of political will on both sides to move beyond a very rocky period in the relationship. 


\section{The future of the June 2008 agreement}

Sino-Japanese energy cooperation has been most successful when it has been a product of both strategic and economic priorities. In the 1970s, China required dollar earnings, Japan sought to diversify away from Middle East oil, and both were trying to balance the Soviet Union. This relationship was close enough to warrant joint development talks on the disputed area of the East China Sea in the 1980s. While the strategic level imperative of cooperation against the USSR ensured a cordial relationship, it was insufficient to engender cooperation on resource development in the disputed area at the time. While the Japanese were of the view that China needed Japanese expertise to exploit the resources of the seabed, China clearly did not view its oil demand has sufficiently dire to warrant joint development of the East China Sea. Paradoxically, Chinese interest in the development of the disputed area of the East China Sea waned following its 1993 shift to net oil-importer status, not least because it opened up exploration blocs in undisputed Chinese areas west of the median line. Japanese commercial interest in China's offshore development remained, but primarily in the Bohai gulf and the South China Sea, where expectations were high. There was no strategic impetus for either party to seek the joint development of disputed East China Sea resources, not least because of the political symbolism associated with the Senkaku/Diaoyu islands amid a worsening bilateral relationship through the 1990s.

These conditions changed following the dramatic rise in the oil price in 2004 Chinese and Japanese energy insecurity rapidly increased tensions over the development of the Chunxiao field. Chinese oil companies did not need Japanese investment or technology to exploit Chunxiao, which dramatically reduced Japan's bargaining power. Following the nadir period of April 2005, and the end of Koizumi's leadership, both parties became willing to improve relations. In this climate, progress was made on joint development. Similar to Sino-Japanese energy cooperation in the 1970s, cooperation was driven by the strategic imperative of improving relations from their lowest point in the context of high global oil prices; energy cooperation once again was part of an improvement in Sino-Japanese relations.

What does this hold for the June 2008 agreement? The survey presented here indicates that economic and strategic factors worked in tandem to create the impetus for meaningful cooperation. In this context, the recent collapse of the global oil price has arguably removed an economic incentive for cooperative resource development Nevertheless, as noted in the first section, East China Sea resources are consistent with both Chinese and Japanese energy security objectives. Therefore, in light of the apparent political will to improve the bilateral relationship since mid-2006, the most effective path to cooperation is one that relies on political interest to fill the economic void. If Japan and China were to proceed with joint resource exploration in the JDZ despite the poor market conditions, they would create an impetus for cooperation that could become sustainable if oil prices return to their former levels. This could be accomplished if both sides funded their government-backed oil companies to conduct joint exploration in the JDZ. Alternatively, waiting for oil prices to return to former highs, particularly given current global economic forecasts, risks eroding the politica will that created the June 2008 agreement and the improvement of bilateral relations. Oil companies in both states have links with government but will not commence joint exploration under current market conditions unless the additional costs are borne by national governments. Funding joint resource development now strengthens the June 2008 agreement so that it may outlast any subsequent downturn in the relationship. Failure to do so could see the return of the zero-sum perspective on energy and territorial disputes that has characterized Sino-Japanese relations since the end of the cold war. At the very least, the East China Sea case indicates that East Asia's maritime territorial disputes are not necessarily predisposed toward violent conflict.

\section{Notes}

James Manicom is a $\mathrm{PhD}$ candidate, School of Political and International Studies, Flinders University, Australia, and is best reached at james.manicom@flinders.edu.au This article is a revised version of a conference paper presented to the Second Australasian Conference on Economics and Politics of War and Peace, Macquarie University, Sydney, 25-26 July 2008. He acknowledges the support of the Endeavour International Postgraduate Research Scholarship.

1. Liao (2007, pp. 34-37).

2. Tow (2007, p. 161).

3. Lee (2005); Kenny (2004).

4. Lai (2007, p. 535).

5. For a comprehensive analysis of the delimitation and legal issues see Valencia (2007); Dutton (2007)

\section{EIA (2008).}

7. Cole (2003, p. 27).

8. Andrews-Speed (2004, p. 132).

9. $\operatorname{ANRE}(2006$, pp. 2-4).

10. Xinhua News (2008). This is an English translation of the agreement 
(C) www.epsjournal.org.uk - Vol. 4, No. 2 (2009)

11. Platt's Oilgram (2004). This effectively amounts to Japanese recognition of Chinese sovereignty over the Chunxiao field. Japanese companies would be bound by Chinese domestic laws, as were Shell and Unocal prior to their exit from the project in September 2004.

12. Japan Times (2009).

13. Chow (1992).

14. Valencia (1989, p. 53).

15. Johnston and Valencia (1991, p. 109).

16. Tarim basin: Oil \& Gas Journal (1991). Some argue: Paik (1995, p. 36). Significant advances: Anonymous (1993). Japanese consortium: Petroleum Economist (1994). Absence of other bids: Paik (1995, p. 38).

17. This section draws on Yarita (2005, pp. 23-28).

18. Johnston and Valencia (1991, p. 105); Petroleum Economist (1996a).

19. Asian Development Bank: Petroleum Economist (1996b). Embarrassingly revealed: Yomiuri Shimbun (2005).

20. Au (2008); Manicom (2008).

\section{References}

Andrews-Speed, P. 2004. Energy Policy and Regulation in the People's Republic of China. The Hague: Kluwer Law International.

Anonymous. 1993. "Sino-Japanese Joint Venture Starts up at Lufeng Field in South China Sea." Oil \& Gas Journal. Vol. 91, No. 41, p. 24.

[ANRE] Agency for Natural Resources and Energy. 2006. "Energy Security Study Group Interim Report.”http://www.enecho.meti.go.jp/english/archives_2006.htm [accessed 31 March 2007].

Au, K.W. 2008. “The East China Sea Issue: Japan-China Talks for Oil and Gas.” East Asia. Vol. 25, pp. 223-241.

Chow, L.C. 1992. "The Changing Role of Oil in Chinese Exports 1974-1989." The China Quarterly. No. 131, pp. 750-765.

Cole, B.D. 2003. "Oil for the Lamps of China: Beijing's 21st Century Search for Energy." McNair Papers, No. 27. Washington, D.C.

[EIA] Energy Information Administration. "East China Sea." U.S. Department of
Energy. http://www.eia.doe.gov/emeu/cabs/East_China_Sea/Background.html [accessed 3 July 2007].

Harrison, S.S. 1977. China, Oil and Asia: Conflict Ahead? New York: Columbia University Press.

[Japan Times] 2009. "Joint Project with China.” Japan Times. 29 January 2009.

Johnston, D.M. and M.J. Valencia. 1991. Pacific Ocean Boundary Problems: Status and Solutions. Dordrecht: Martinus Nijhoff Publishers.

Kenny, H.J. 2004. "China and the Competition for Oil and Gas in Asia." Asia-Pacific Review. Vol. 11, No. 2, pp. 36-47.

Lai, H.H. 2007. "China's Oil Diplomacy: Is It a Global Security Threat?” Third World Quarterly. Vol. 28, No. 3, pp. 519-537.

Liao, X. 2007. "The Petroleum Factor in Sino-Japanese Relations: Beyond Energy Cooperation." International Relations of the Asia-Pacific. Vol. 7, No. 1, pp. 23-46.

Lee, P.K. 2005. "China's Quest for Oil Security: Oil (Wars) in the Pipeline?" The Pacific Review. Vol. 18, No. 2, pp. 265-301.

Manicom, J. 2008. "Sino-Japanese Cooperation in the East China Sea: Limitations and Prospects." Contemporary Southeast Asia. Vol. 30, No. 3, pp. 455-478.

[Oil \& Gas Journal] 1991. "JNOC to Fund First Tarim Foreign Joint Venture." Oil \& Gas Journal. Vol. 89, No. 18, p. 143.

Paik, K.W. 1995. Gas and Oil in Northeast Asia: Policies, Projects and Prospects. London: Royal Institute of International Affairs.

[Platt's Oilgram] 2004. "Shell, UNOCAL Exit East China Sea Project; CNOOC Says It Still Intends to Start Output in Mid-2005." Platt's Oilgram. 30 September 2004

[Petroleum Economist] 1994. "Japanese Consortium Wins Blocks 41/17 and 42/03 in East China Sea.” Petroleum Economist. 19 January 1994.

[Petroleum Economist] 1996a. "Drillship Enters Senkaku Area." Petroleum Economist. 1 March 1996.

[Petroleum Economist] 1996b. “Asian Development Bank Approves Loan to Develop Ping Hu Oil/Gasfield in East China Sea.” Petroleum Economist. 28 February 1996.

Tow, W.T. 2007. "Strategic Dimensions of Energy Competition in Asia," pp. 161-173 in M. Wesley, ed. Energy Security in Asia. New York: Routledge.

Valencia, M.J. 2007. "The East China Sea Dispute: Context, Claims, Issues, and Possible Solutions.” Asian Perspective. Vol. 31, No. 1, pp. 127-167.

Valencia, M.J. 1989. "Northeast Asia: Petroleum Potential, Jurisdictional Claims, and International Relations." Ocean Development and International Law. Vol. 20, pp. 35-61.

[Xinhua News] 2008. “China, Japan Reach Principled Consensus on East China Sea Issue." Xinhua News. 18 June 2008.

Yarita, S. 2005. "Toward Cooperation in the East China Sea." Paper presented at the Seabed Petroleum in the East China Sea: Geological Prospects, Jurisdictional 
(C) www.epsjournal.org.uk - Vol. 4, No. 2 (2009)

Conflicts and Paths to Cooperation. Beijing, 12-13 April 2005.

[Yomiuri Shimbun] 2005. "Govt Funded Pipeline for China." Yomiuri Shimbun. 25 February 2005. 